\title{
Investigation of Antimicrobial Activity of Different Trametes versicolor Extracts on Some Clinical Isolates
}

\author{
Farklı Trametes versicolor Özütlerinin Bazı Klinik İzolatlar \\ Üzerindeki Antimikrobiyal Aktivitesinin İncelenmesi
}

\author{
Research Article
}

Erkay Özgör*, Meltem Ulusoy, İrem Çelebier, Semiha Selda Yıldız, Nevin Keskin

Hacettepe University, Department of Biology, Microbiology and Parasitology Laboratory, Beytepe, Ankara, Turkey

\section{A B STR ACT}

\begin{abstract}
ntensive drug uses against species which have clinical significance and cause severe diseases have triggered the development of resistance in these species. It is necessary to discover new potential drugs against clinical isolates because many antimicrobial drugs become ineffective in the coming years. In this research, we used different extracts from Trametes versicolor fruiting bodies for investigating antibacterial and antifungal activities on some clinical isolates. For this purpose, five bacterial species (Staphylococcus aureus, Enterococcus faecalis, Bacillus subtilis, Escherichia coli and Pseudomonas aeruginosa) and a fungal species (Candida albicans) were selected as clinically important isolates and four different crude extracts (chloroform, water, ethyl acetate and ethyl alcohol) of Trametes versicolor were tried on these species in terms of antimicrobial sensitivity with disc diffusion method. Obtained data were analyzed using SPSS 14 software. At the result, some of extracts were found to have antimicrobial activity on clinical isolates although all extracts generally show antimicrobial effect. Chloroform extract was found to have the highest antimicrobial activity on S. aureus and $E$. faecalis while ethanol extract was observed as more effective on $P$. aeruginosa, $E$. coli, $B$. subtilis and C. albicans isolates. It can therefore be suggested that, some of Trametes versicolor extracts are promising antimicrobial agents.
\end{abstract}

\section{Key Words}

Trametes versicolor, Antimicrobial activity, Antifungal activity, Clinical isolates.

\section{ÖZET}

\begin{abstract}
L linik önemi olan ve ciddi hastalıklara sebep olan türlere karşı yoğun ilaç kullanımı bu türlerde direnç gelişimini tetiklemektedir. İlerleyen yıllarda birçok antimikrobiyal ilaç etkisiz hale geleceğinden bu türlere karşı yeni potansiyel ilaçların keşfedilmesi gereklidir. Bu araştırmada, Trametes versicolor üreme yapılarından elde edilen farklı özütler, bazı klinik izolatlar üzerinde antibakteriyel ve antifungal aktiviteleri araştırmak için kullanılmıştır. Bu amaç doğrultusunda, klinik önemi olan izolatlar olarak 5 bakteri türü (Staphylococcus aureus, Enterococcus faecalis, Bacillus subtilis, Escherichia coli, Pseudomonas aeruginosa) ile bir fungus türü (Candida albicans) seçildi ve Trametes versicolor'un 4 farklı ham özütünün (kloroform, su, etil asetat, etil alkol), bu türler üzerinde antimikrobiyal duyarlılık açısından disk difüzyon yöntemi kullanılarak denendi. Elde edilen veriler SPSS 14 programı kullanılarak analiz edildi. Çalışmanın sonunda, tüm özütler genel olarak antimikrobiyal etki gösterse de özütlerden bazılarının klinik izolatlar üzerinde antimikrobiyal aktiviteye sahip olduğu bulunmuştur. Kloroform özütünün S. aureus ve E. faecalis üzerinde en yüksek antimikrobiyal aktiviteye sahip olduğu bulunurken etanol özütünün $P$. aeruginosa, $E$. coli, B. subtilis ve $C$. albicans izolatları üzerinde daha etkili olduğu gözlenmiştir. Bu nedenle, bazı Trametes versicolor özütlerinin umut verici antimikrobiyal ajanlar olabileceği söylenebilir.
\end{abstract}

\author{
Anahtar Kelimeler \\ Trametes versicolor, Antimikrobiyal aktivite, Antifungal aktivite, Klinik izolatlar.
}

Article History: Received: Jan 19, 2016; Revised: May 16, 2016; Accepted: Jun 20, 2016; Available Online: Jul 31, 2016.

DOI: 10.15671/HJBC.20164420569

Correspondence to: E. Özgör, Hacettepe University, Department of Biology, Microbiology and Parasitology Laboratory, Beytepe, Ankara, Turkey 


\section{INTRODUCTION}

- ungi have been a very good source of many medical compounds for thousands of years. Fungal substances have been as important source of lead structures for new drug compounds. Due to the discovery of penicillin that led to later discoveries of potent antibiotics isolated from microbial habitats [1,2]. In the last decades, problem with antibiotic resistant bacteria has emerged because of the wrong and intensive drug uses. Bacterial and fungal pathogens have evolved numerous defense mechanisms against antimicrobial agents, and nowadays, the need to discover new and more potent of these agents as alternative to antibiotic therapy is stronger [3-5].

There are many different studies about antimicrobial activity of different types of fungal extracts from Slovakia, Nigeria, India and China [3,6-9]. In these studies, fungal extracts have been shown to be a potential drug against bacterial and fungal disease agents. Studies with macromycetes, especially Ganoderma lucidum and Trametes versicolor, revealed that these fungi have effective microbial inhibitory properties.

Trametes versicolor (L.) which commonly known as turkey tail is a common polypore mushroom found throughout the world. The top surface of the cap shows typical concentric zones of different colours. The fruiting body is 1-3 $\mathrm{mm}$ thick and has leathery texture. T. versicolor contains biologically active compounds with an enormous variety of chemical structures including the protein-bound PSP, B-1,3-B-1,4 glucans, tetracyclic triterpenoids of lanostane, fungisterol and B-sitosterol [10-12]. Furthermore, Polysaccharide-K (PSK) which can be obtained from mushrooms displays anticancer activity in laboratory studies and preliminary human researches $[13,14]$. Therefore, Trametes spp. could be useful in the search of new potent antimicrobial agents.

The aim of this study is to investigate antibacterial and antifungal activities of different extracts from Trametes versicolor fruiting bodies against some clinical isolates including Grampositive, Gram-negative bacteria and Candida albicans.

\section{MATERIALS and METHODS}

\section{Preparation of Different Trametes versicolor Extracts}

Trametes versicolor fruiting bodies were collected almost 500 gram from different forest areas in Ankara and Zonguldak provinces, Turkey during the spring season 2015 and macroscopic identification of harvested fungi were done. Fruiting bodies of $T$. versicolor were dried at $70^{\circ} \mathrm{C}$ and pulverized with laboratory blender. The obtained powder was weighed and divided into four groups. Each group was treated with 500 $\mathrm{mL}$ of four different solvent (chloroform, water, ethyl acetate and ethyl alcohol) to find out which solvent requires to obtain active compounds from T. versicolor fruiting bodies. Powdered substances in each extract were dissolved with the aid of sonicator. After this process, each mixture was filtered to remove solid residues and solvents evaporated with rotary evaporator. The crude residue of each extract was frozen at $-80^{\circ} \mathrm{C}$ and Iyophilized [3]. These fungi extracts were stored at $+4^{\circ} \mathrm{C}$ in refrigerator until use.

\section{Test Microorganisms}

Six clinically important strains of microorganisms were tested in this research. Three Grampositive bacteria (Bacillus subtilis ATCC 6633, Staphylococcus aureus ATCC 25923, Enterococcus faecalis ATCC 29212) and two Gramnegative bacteria (Escherichia coli ATCC 25922, Pseudomonas aeruginosa ATCC 27853) were selected for antibacterial activity test. Candida albicans ATCC 10231, a clinically important yeast strain, was also selected for antifungal activity test. Staphylococcus aureus and Enterococcus faecalis were cultured in the blood agar (SigmaAldrich, USA) at $37^{\circ} \mathrm{C}$, Bacillus subtilis, Escherichia coli and Pseudomonas aeruginosa were cultured in the nutrient agar (Merck, Germany) at $37^{\circ} \mathrm{C}$ and Candida albicans was cultured in the sabouraud dextrose agar (Merck, Germany) at $30^{\circ} \mathrm{C}$.

\section{Antimicrobial Assay}

Antibacterial and antifungal activity tests were performed with disc diffusion method to find antimicrobial sensitivities of selected clinical isolates. Different Fungal extracts dissolved in 
DMSO were prepared to a final concentration of $200 \mu \mathrm{g} / \mathrm{mL}$. These solutions were regarded as $100 \%$ concentration and were diluted 1:1 ratio with DMSO to obtain $50 \%$ concentrations. Suspensions of all test microorganisms were prepared in eppendorf tubes with using sterile distilled water. Each tube was adjusted with microbial suspension at the final density of $0.5 \mathrm{McF}^{\circ}$. Antibiotics known to be inhibition effect on isolates were used as a positive control and DMSO was used as a negative control during disc diffusion method. Vancomycin was used for $S$. aureus and E. faecalis, Erythromycin for B. subtilis, Norfloxacin for E. coli, Piperacillin-tazobactam for $P$. aeruginosa and Polymyxin B for C. albicans as an antibiotic. To obtain meaningful results, microbial inoculations were repeated three times for each parameter. $100 \mu \mathrm{l}$ of microbial suspension was inoculated into respective medium for each petri dish by spread plate technique at disc diffusion method. Discs were placed inoculated petri dishes and $100 \%$ and $50 \%$ concentrations of crude extracts were added $15 \mu \mathrm{l}$ on blank discs $(5 \mathrm{~mm})$. After incubation at $37^{\circ} \mathrm{C}$ for bacteria and $30^{\circ} \mathrm{C}$ for yeast for 36 hours, the inhibition of microbial growth was evaluated by measuring zone diameters.

\section{Statistical Analysis}

After disc diffusion method, SPSS 14 software was used for statistical evaluation of zone diameters (in millimeters) measurement data. The comparison of different extracts in each isolate and between isolates was performed with one-way ANOVA. These results were obtained in $95 \%$ confidence intervals. The most effective extract was also evaluated with Duncan test for each clinical isolate.

\section{RESULTS}

The amounts of crude residues which are lyophilisates of four different extracts made from Trametes versicolor fruiting bodies are shown in Table 1. Even though the products were obtained with different amounts of each extract, standardization is made using the residue in the same proportions during disc diffusion method.

The antimicrobial activity (expressed as $\mathrm{mm}$ ) of four different fungi extracts from Trametes versicolor against various strains of bacteria and yeast are summarized in Table 2. Although all extracts generally show antimicrobial effect, some of them were found to have antimicrobial activity on clinical isolates.

The comparison of zone diameters showed that there is a significant difference between the zones when extracts of $100 \%$ and $50 \%$ concentrations compared with positive and negative controls $(p<0.05)$. Antibiotics used as positive control were found to be most effective on all isolates. However, Different Trametes versicolor extracts were found to have microbial inhibition due to the negative control by Duncan test (Table 3). Although it was not seen a significant difference between the concentrations of the extracts, it was found to be more effective in $100 \%$ concentration of extracts ( $p>0.05)$.

There was no significant difference between the extracts when the antimicrobial activity of the extracts on all isolates compared with one way ANOVA ( $p>0.05)$. However, there were significant differences in the comparisons for each isolate $(p$ $<0.05)$. Chloroform extract was found to have the highest antimicrobial activity on S. aureus and E. faecalis (Figure 1) while ethanol extract was observed to be more effective on $P$. aeruginosa, E. coli, B. subtilis and C. albicans isolates (Figure 2). Furthermore, we did not determine significant antimicrobial activity of tested water and ethyl acetate extracts against selected clinical isolates.

\section{DISCUSSION}

Many researchers who tested different macromycetes extracts against bacteria and yeast observed their antimicrobial activities. Macromycetes extracts contain lots of active chemical compounds which show potential antimicrobial activities. For example, terpenes, organic acids, benzoic acid derivates and quinolone were isolated from some species such as Ganoderma spp., Lentinus edodes and Leucopaxillus albissimus showed activity against many different species of bacteria and yeast $[1,10,15-18]$.

Many different species of macrofungi extracts were tested against different bacteria 
Table 1. The amounts of crude residues obtained from four different Trametes versicolor extracts.

\begin{tabular}{cc}
\hline Extracts & Weight (mg) \\
\hline Ethyl Alcohol & 98 \\
\hline Ethyl Acetate & 83 \\
\hline Chloroform & 124 \\
\hline Water & 149 \\
\hline
\end{tabular}

Table 2. Antimicrobial activity of different Trametes versicolor extracts against clinical isolates tested by disc diffusion method.

\begin{tabular}{cccccccccc}
\hline & \multicolumn{2}{c}{ Ethanol } & \multicolumn{2}{c}{ Ethyl acetate } & \multicolumn{2}{c}{ Chloroform } & \multicolumn{2}{c}{ Water } \\
\cline { 2 - 9 } & $100 \%$ & $50 \%$ & $100 \%$ & $50 \%$ & $100 \%$ & $50 \%$ & $100 \%$ & $50 \%$ \\
\hline P.aeruginosa & 10.33 & 9.33 & 6.00 & 6.67 & 7.33 & 7.33 & 7.00 & 7.33 \\
\hline S.aureus & 5.33 & 5.00 & 7.33 & 5.67 & 10.00 & 12.33 & 5.00 & 5.00 \\
\hline E.faecalis & 6.33 & 6.33 & 5.67 & 6.33 & 6.33 & 7.33 & 5.33 & 5.33 \\
\hline B.subtilis & 9.33 & 8.67 & 6.00 & 5.00 & 6.33 & 8.33 & 8.67 & 7.00 \\
\hline E.coli & 9.67 & 9.33 & 6.33 & 6.33 & 7.00 & 8.67 & 9.00 & 8.67 \\
\hline C.albicans & 9.00 & 6.67 & 7.00 & 5.67 & 6.33 & 6.33 & 7.33 & 5.00 \\
\hline
\end{tabular}

Values are mean inhibition zone of three replicates $(\mathrm{mm})$.

Table 3. The comparison of $100 \%$ (A) and $50 \%$ (B) concentration of extracts with positive and negative controls.

\begin{tabular}{ccccc}
\hline \multirow{2}{*}{ CONS } & & \multicolumn{3}{c}{ Subset for alpha $=0.05$} \\
\cline { 3 - 4 } Duncan $^{\mathrm{a}} \mathrm{N}$ & & 1 & 2 & 3 \\
\hline $50 \%$ & 72 & 5.01 & 7.07 & 19.83 \\
\hline $100 \%$ & 72 & & 7.21 & 1.000 \\
\hline Sig. & 72 & & 0.79 & \\
\hline
\end{tabular}

Means for groups in homogeneous subsets are displayed. a. Uses Harmonic Mean Sample Size $=72.000$.

by Suay et al., [12]. These researchers determined and confirmed antimicrobial activity of crude macrofungi extracts.

From the obtained results, it could be observed that ethanol was the best solvent for extracting antimicrobial compounds from Trametes versicolor. This suggestion was based on the number of organisms inhibited and the diameter of inhibitory zones produced. Furthermore, chloroform extract of Trametes versicolor has effect against $S$. aureus and E. faecalis known as infectious disease agents. These results demonstrated that various active compounds can be isolated from different fungal extracts. Thus, fungal extraction with different solvents should be performed in order to obtain active compounds to inhibit each clinical isolate. Comparison of the concentrations $(100 \%$ and $50 \%$ ) of extracts revealed that there is no significant difference between the concentrations (Table 3). According to this result, inhibition of clinical isolates can be performed with the lesser amount of active compounds.

In conclusion, this study has shown that different extracts (ethyl alcohol, ethyl acetate, chloroform and water) have been used in-vitro 


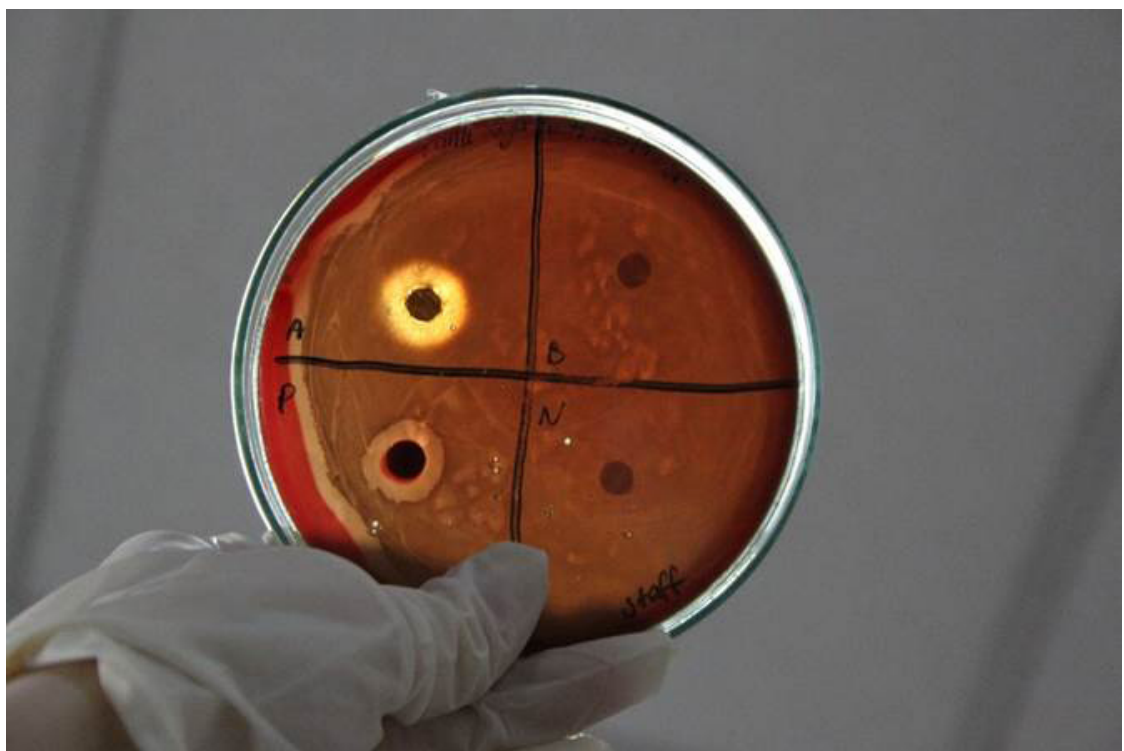

Figure 1. Evaluation of antimicrobial effect of chloroform extracts of Trametes versicolor on Staphylococcus aureus by disc diffusion method.

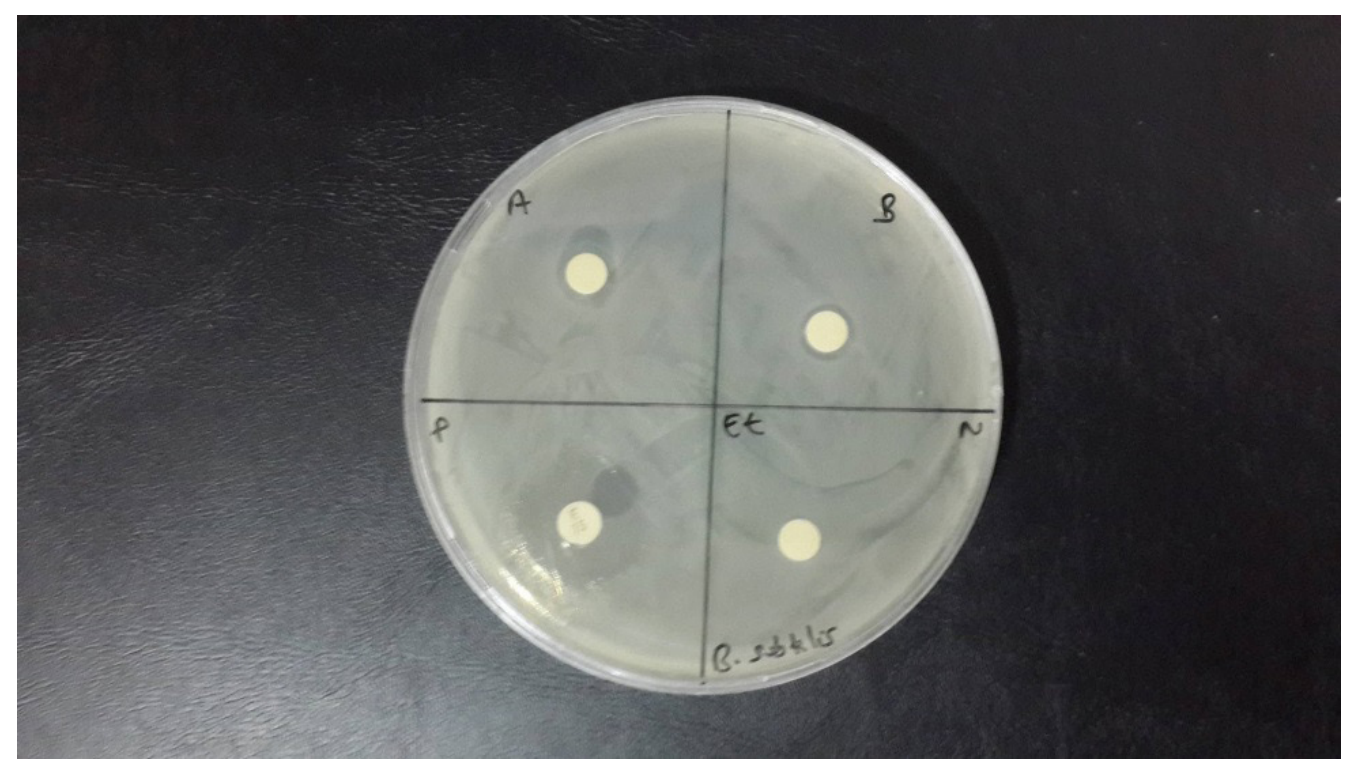

Figure 2. Evaluation of antimicrobial effect of ethanol extracts of Trametes versicolor on Bacillus subtilis by disc diffusion method.

to inhibit the growth of some disease causing bacteria and yeast. It can therefore be suggested that, some of extracts are promising antimicrobial agents.

\section{ACKNOWLEDGEMENTS}

We would like to express our thanks to Öznur İrem Yayalar and Nermin Nazlı Ayan for help the collection of fungi samples and Öyküm Öztürk for attribution to detect Trametes versicolor macroscopic identification.

\section{References}

1. M. Corrado, K.F. Rodrigues, Antimicrobial evaluation of fungal extracts produced by endophytic strains of Phomopsis sp., Journal of Basic Microbiology, 44 (2004) 157-160.

2. R. Pinner, S. Teutsch, L. Simonsen, L. Klug, J. Graber, M. Clarke, R. Berkelman, Trends in infectious diseases mortality in the united states, Journal of the American Medical Association, 275 (1996) 189-193. 
3. L. Heba, N. Vukovi, J. Petrová, M. Kaániová Antimicrobial activity of crude methanolic extracts from Ganoderma lucidum and Trametes versicolor, Animal Science and Biotechnologies, 47 (2014) 89-93.

4. M.S. Butler, The role of natural product chemistry in drug discovery, Journal of Natural Products, 67 (2004) 2141-2153.

5. K.S. Lam, New aspects of natural products in drug discovery, Trends in Microbiology, 15 (2007) 62796289.

6. N. Sheena, T.A. Ajith, A.T. Mathew, K.K. Janardhanan, Antibacterial activity of three macrofungi, Ganoderma lucidum, Navesporus floccosa and Phellinus rimosus occuring in South India, Pharmaceutical Biology, 41 (2003) 564-567.

7. S. Quereshi, A.K. Pandey, S.S. Sandhu, Evaluation of antibaterial activity of different Ganoderma lucisum extracts, Journal of Scientific Research, 3 (2010) 9-13.

8. Y. Gao, W. Tang, H. Gao, E. Chan, J. Lan, X. Li, S. Zhou, Antimicrobial activity of medical mushrooms Ganoderma, Food Reviews International, 21 (2005) 211-222.

9. S.G. Jonathan, I.O. Fasidi, Antimicrobial activities of two nigerian edible macro-fungi Lycoperdon pusilum (bat. ex) and Lycoperdon giganteum (pers.), African Journal of Biomedical Research, 6 (2003) 85-90.

10. M.J. Alves, I.C.F.R. Ferreira, J. Dias, V. Teixeira, A. Martins, M. Pintado, A review on antimicrobial activity of mushrooms (Basidiomycetes) extracts and isolated compounds, Planta Medica, 78 (2012) 17071718.

11. A. Yokoyama, Distribution of tetracyclic triterpenoids of lanostane group and sterols in higher fungi especially of the polyporacea and related families, Phytochemistry, 14 (1975) 487-497.

12. S. Endo, Lipids of five species of Polyporacea, Tokyo Gakugei, 16, 1981.
13. A. Yamasaki, M. Shoda, H. Iijima, S. Nagai, J. Wada, H. Suzuki, N. Chikazawa, T. Tasaka, C. Kameda, H. Tanaka, M. Ikebe, E. Jo, N. Sato, M. Nakamura, F. Sekine, T. Morisaki, M. Katano, A protein-bound polysaccharide, PSK, enhances tumor suppression induced by docetaxel in a gastric cancer xenograft model, Anticancer Research, 29 (2009) 843-50.

14. K. Oba, S. Teramukai, M. Kobayashi, T. Matsui, Y. Kodera, J. Sakamoto, Efficacy of adjuvant immunochemotherapy with polysaccharide $K$ for patients with curative resections of gastric cancer, Cancer Immunology and Immunotherapy, 56 (2007) 905-1011.

15. S.Keypour, H. Riahi, M. F. Moradali, H. Rafati, Investigation of the Antibacterial Activity of a Chloroform Extract of Ling Zhi or Reishi Medicinal Mushroom, Ganoderma Iucidum (W. Curt.: Fr.) P. Karst. (Aphyllophoromycetideae), from Iran, International Journal of Medicinal Mushrooms, 10 (2008) 345-349.

16. R. Balakumar, E. Sivaprakasam, D. Kavitha, S. Sridhar, J.S. Kumar, Antibacterial and antifungal activity of fruit bodies of Phellinus mushroom extract, International Journal of Biosciences, 1 (2011) 72-77.

17. D. Kavitha, R. Balakumar, E. Sivaprakasam, S. Sridhar, J. Suresh, Antibacterial and antifungal potential of fruit body extracts from daldinia concentrica (bolton) cesati \& de notaris, International journal of pharmaceutical sciences and research, 2 (2011) 23762379.

18. H. Zheng, Y. Maoqing, X. Liqiu, T. Wenjuan, L. Lian, Z. Guolin, Purification and characterization of an antibacterial protein from the cultured mycelia of Cordyceps sinensis, Wuhan University Journal of Natural Sciences, 11 (2006) 709-714. 